\title{
Knowledge of haemodialysis patients concerning methods of preventing hyperphosphataemia
}

\author{
Wiedza chorych hemodializowanych na temat metod zapobiegania \\ hiperfosfatemii \\ Anna M. Janus ${ }^{1}\left(\mathbb{D}\right.$, Michał Holecki² (D), Anna Hawrot-Kawecka3 ${ }^{(1 D}$, Grzegorz Kawecki ${ }^{4}$ \\ ${ }^{1}$ Faculty of Health Sciences in Katowice, Medical University of Silesia, Katowice, Poland \\ 2Department of Internal Medicine, Autoimmune and Metabolic Diseases, Faculty of Medical Sciences in Katowice, \\ Medical University of Silesia, Katowice, Poland \\ ${ }^{3}$ Department of Internal Medicine and Metabolic Diseases, Faculty of Health Sciences in Katowice, \\ Medical University of Silesia, Katowice, Poland \\ ${ }^{4}$ Department of Nephrology Nefrolux Dąbrowa Górnicza
}

\begin{abstract}
INTRODUCTION: The beginning of renal replacement therapy is generally connected with changing dietary habits. A positive phosphate balance is a major clinical problem, often observed in haemodialysis patients. The treatment of hyperphosphataemia is based primarily on dietary intervention and the use of phosphate binders - medications which bind phosphorus in the gastrointestinal tract. Properly conducted education of patients with CKD helps to perceive the risks resulting from an improper diet.

MATERIAL AND METHODS: The diagnostic survey method with author's own survey questionnaire was used in the study. The survey contained closed questions concerning the knowledge of dietary recommendations for haemodialysis patients enabling the maintenance of the recommended phosphatemia. Statistical analysis was performed with SAS 9.4 software (SAS Institute Inc., Cary, North Carolina, USA), assuming the statistical significance level $p<0.05$. The following tests were applied: chi-squared test/Fisher's exact test, due to the small size of subgroups - the Kruskal-Wallis test for comparison of three groups, and the Mann-Whitney U test to compare the two groups.

RESULTS: Haemodialysis patients were aware of the need for restrictions on the consumption of products with a high phosphorus content, but had problems choosing those recommended when composing meals. The right set of meats was chosen by 44 patients (36\%). Dairy consumption in a moderate amount was declared by 74 people (61\%). 46 respondents $(38 \%)$ reduced their egg yolk consumption. Out of the range of available cheeses, 92 respondents $(76 \%)$ declared the consumption of mainly curd cheese. The right set of bakery products was indicated by 31 patients $(26 \%)$, and 73 patients $(60 \%)$ avoided carbonated beverages.

CONCLUSIONS: Patients' knowledge concerning the possibilities of preventing hyperphosphataemia was far from insufficient.
\end{abstract}

KEY WORDS

chronic kidney disease, hyperphosphatemia, dietary recommendations for patients under haemodialysis

Received: 15.08.2019 Revised: 04.09.2019 Accepted: 25.10.2019 Published online: 09.04.2020

Address for correspondence: Anna M. Janus, Wydział Nauk o Zdrowiu w Katowicach, Śląski Uniwersytet Medyczny w Katowicach, ul. Medyków 12 , 40-752 Katowice, Polska, tel. + 48604612 178, e-mail: annajanus.janus@gmail.com

Copyright @ Śląski Uniwersytet Medyczny w Katowicach

www.annales.sum.edu.pl 


\section{STRESZCZENIE}

WSTĘP: Rozpoczęcie leczenia nerkozastępczego wiąże się zasadniczo ze zmianą stylu odżywiania. Istotnym problemem klinicznym, często obserwowanym u chorych hemodializowanych, jest dodatni bilans fosforanowy. Postępowanie w przypadku hiperfosfatemii opiera się przede wszystkim na interwencji dietetycznej i stosowaniu leków wiążących fosfor w przewodzie pokarmowym. Właściwie przeprowadzona edukacja chorych na PCHN ułatwia postrzeganie zagrożeń, jakie wynikają z niewłaściwej diety.

MATERIA I METODY: W badaniu zastosowano metodę sondażu diagnostycznego z wykorzystaniem kwestionariusza ankiety własnego autorstwa. Sondaż zawierał pytania zamknięte dotyczące znajomości wskazówek dietetycznych zalecanych chorym hemodializowanym, pozwalających na utrzymanie zalecanej fosfatemii. Analizę statystyczną wykonano w programie SAS wersja 9.4 (SAS Institute Inc., Cary, North Carolina, USA), przyjmując poziom istotności statystycznej $\mathrm{p}<0,05$. Wykorzystano testy: $\mathrm{Chi}^{2} /$ Fishera $\mathrm{z}$ uwagi na małą liczebność w podgrupach, test Kruskala-Wallisa dla porównania trzech grup oraz test U Manna-Whitneya dla porównania dwóch grup.

WYNIKI: Chorzy hemodializowani byli świadomi konieczności stosowania ograniczeń w spożywaniu produktów z wysoką zawartością fosforu, lecz mieli problemy z wybraniem tych, które są zalecane przy komponowaniu posiłków. Właściwy zestaw mięs wybrało 44 chorych (36\%). Spożycie nabiału w umiarkowanej ilości deklarowały 74 osoby (61\%). Spożycie żółtka jaja kurzego ograniczyło 46 respondentów (38\%). Z puli dostępnych serów spożycie głównie twarogu deklarowało 92 badanych (76\%). Właściwy zestaw pieczywa wskazało 31 pacjentów (26\%), a napojów gazowanych unikało 73 chorych $(60 \%)$.

WNIOSKI: Stan wiedzy chorych na temat możliwości zapobiegania hiperfosfatemii był dalece niewystarczający.

\section{SŁOWA KLUCZOWE}

przewlekła choroba nerek, hiperfosfatemia, wskazówki dietetyczne dla chorych hemodializowanych

\section{INTRODUCTION}

Chronic kidney disease (CKD) is considered to be a civilization disease. It is estimated that it affects over 4 million Poles and its progressive character constitutes a major therapeutic problem [1]. The beginning of renal replacement therapy is connected with a lifestyle change. Dietary management requires, among others, restrictions on certain nutrients. The improper dietary habits of haemodialysis patients result in deterioration of the clinical condition, a worse quality of life and increased mortality. A positive phosphate balance is a major clinical problem, often observed in haemodialysis patients. Hyperphosphataemia results in the development of mineral and bone complications, and an increased serum concentration of inorganic phosphorus, intensifying concomitant hypocalcaemia, secondary to renal failure, stimulates the parathyroid glands to secrete an excess of the parathyroid hormone. Secondary hyperparathyroidism, together with calcium-phosphate disorders, constitute a separate mortality risk factor in this group of patients. It is reasonable to make all possible efforts aimed at reducing hyperphosphataemia in patients with chronic kidney disease [2]. The Dialysis Outcomes and Practice Patterns Study II (DOPPS II) conducted in several countries showed that only $44 \%$ of haemodialysis patients reached the recommended serum phosphorus concentration. One of the potential causes of this condition was the excessive consumption of products rich in phosphorus [3]. The treatment of hyperphosphataemia is based primarily on dietary intervention and the use of phosphate binders - medications which bind phosphorus in the gastrointestinal tract. The restrictions include first and foremost the amount and type of consumed protein and the avoidance of products with ad-

\section{WSTĘP}

Przewlekła choroba nerek (PChN) jest schorzeniem uznanym za chorobę cywilizacyjną. Szacuje się, że dotyczy ponad 4 milionów Polaków, a jej postępujący charakter stanowi istotny problem terapeutyczny [1]. Rozpoczęcie leczenia nerkozastępczego wiąże się ze zmianą stylu życia. Postępowanie dietetyczne wymaga m.in. zastosowania ograniczeń w stosunku do niektórych składników pokarmowych. Niewłaściwy sposób odżywiania chorych hemodializowanych przekłada się na pogorszenie stanu klinicznego, gorszą jakość życia i zwiększoną śmiertelność. Istotnym problemem klinicznym, często obserwowany w tej grupie chorych, jest dodatni bilans fosforanowy. Hiperfosfatemia skutkuje rozwojem powikłań mineralno-kostnych, a zwiększone stężenie fosforu nieorganicznego w surowicy, nasilając współistniejącą, wtórną do niewydolności nerek hipokalcemię, pobudza przytarczyce do nadmiernego wydzielania parathormonu. Wtórna nadczynność przytarczyc wraz z zaburzeniami gospodarki wapniowo-fosforanowej stanowią niezależny czynnik ryzyka zgonu w tej grupie chorych. Zasadne jest podejmowanie wszelkich możliwych starań prowadzących do zmniejszenia hiperfosfatemii u chorych na przewlekłą chorobę nerek [2]. W badaniu DOPPS II, przeprowadzonym w kilku krajach, wykazano, że zaledwie u 44\% hemodializowanych chorych osiągnięto zalecane stężenie fosforu w surowicy. Jedną z potencjalnych przyczyn takiego stanu było nadmierne spożycie produktów bogatych w fosfor [3]. W przypadku hiperfosfatemii postępowanie oparte jest przede wszystkim na interwencji dietetycznej i stosowaniu leków wiążących fosfor w przewodzie pokarmowym. Ograniczenia obejmują przede wszystkim ilość i rodzaj spożytego białka oraz 
ded preservatives [3]. Preservatives used during food production are a source of so-called "hidden phosphorus" and significantly impede maintaining the homeostasis of this element in haemodialysis patients [4]. The research conducted by Afrasiabifar et al. showed that training repeated periodically by nurses had a positive effect on the results of laboratory tests of the educated patients $[5,6]$.

\section{AIM OF THE STUDY}

The aim of the study was to assess the knowledge of haemodialysis patients concerning dietary management in the prevention of hyperphosphataemia. The research problems were formulated in the form of the following questions:

1. What was the patient's knowledge concerning the prevention of hyperphosphataemia?

2. Is there a greater knowledge deficit in the group of patients with hyperphosphataemia than in the group of patients with a normal serum phosphate concentration?

3. Did women take more notice of dietary recommendations than men?

4. Did the time of renal replacement treatment affect the knowledge of the studied patients?

\section{MATERIALS AND METHODS}

121 haemodialysis patients were observed, among whom 61 patients (including 39\% of women) aged 50.6 \pm 15.6 had at least a two-fold higher phosphate concentration in the last six months and 60 patients (including $38 \%$ of women) aged $62.9 \pm 14.6$, whose phosphate concentration in the last six months did not exceed the recommended standards. The study was conducted from March 2016 to May 2016 in two private dialysis centres. The management of both centres agreed to conduct the survey, the respondents participated in it voluntarily and were assured of their anonymity. The diagnostic survey method with the author's own survey questionnaire was used in the study. The survey contained closed questions concerning the knowledge of dietary recommendations for haemodialysis patients enabling the recommended phosphatemia to be maintained. Statistical analysis was performed with SAS 9.4 software (SAS Institute Inc., Cary, North Carolina, USA), assuming the statistical significance level $p<0.05$. The following tests were applied: chi-squared test/Fisher's exact test, due to the small size of subgroups - the Kruskal-Wallis test for comparison of three groups, and the Mann-Whitney U test to compare the two groups. unikanie produktów z dodatkiem środków konserwujących [3], stosowanych podczas wytwarzania żywności, które stanowią źródło tzw. ukrytego fosforu i znacznie utrudniają zachowanie homeostazy tego pierwiastka $\mathrm{u}$ hemodializowanych chorych [4]. Badania przeprowadzone przez Afrasiabifar i wsp. wykazały, że cyklicznie powtarzane przez pielęgniarki szkolenia miały pozytywny wpływ na wyniki badań laboratoryjnych edukowanych chorych $[5,6]$.

\section{CEL BADANIA}

Celem pracy była ocena stanu wiedzy chorych hemodializowanych na temat postępowania dietetycznego w zapobieganiu hiperfosfatemii. Problemy badawcze sformułowano w postaci następujących pytań:

1. Jaki był stan wiedzy chorych na temat zapobiegania hiperfosfatemii?

2. Czy w grupie chorych z hiperfosfatemią obserwuje się większy deficyt wiedzy niż w grupie chorych $\mathrm{z}$ prawidłowym stężeniem fosforanów w surowicy?

3. Czy kobiety częściej zwracały uwagę na zalecenia dietetyczne niż mężczyźni?

4. Czy czas leczenia nerkozastępczego miał wpływ na stan wiedzy badanych chorych?

\section{MATERIAŁ I METODY}

Obserwacją objęto 121 hemodializowanych chorych, spośród których u 61 osób (w tym 39 \% kobiet) w wieku 50,6 \pm 15,6 lat stwierdzono co najmniej dwukrotnie zwiększone stężenie fosforanów w ostatnim półroczu oraz u 60 chorych (w tym $38 \%$ kobiet) w wieku 62,9 $\pm 14,6$ lat, u których to stężenie w ostatnim półroczu nie przekraczało zalecanych norm. Badanie przeprowadzono od marca do maja 2016 r. w dwóch niepublicznych ośrodkach dializ. Ich dyrekcja wyraziła zgodę na przeprowadzenie sondażu, a respondenci wzięli udział w badaniu dobrowolnie oraz zostali zapewnieni o zachowaniu anonimowości. W badaniu zastosowano metodę sondażu diagnostycznego z wykorzystaniem kwestionariusza ankiety własnego autorstwa. Sondaż zawierał pytania zamknięte dotyczące znajomości wskazówek dietetycznych zalecanych chorym hemodializowanym, pozwalających na utrzymanie zalecanej fosfatemii. Analizę statystyczną wykonano w programie SAS wersja 9.4 (SAS Institute Inc., Cary, North Carolina, USA), przyjmując poziom istotności statystycznej $\mathrm{p}<0,05$. Wykorzystano testy: $\mathrm{Chi}^{2} /$ Fishera $\mathrm{z}$ uwagi na małą liczebność w podgrupach, test Kruskala-Wallisa dla porównania trzech grup oraz test U Manna-Whitneya dla porównania dwóch grup. 


\section{STUDY RESULTS}

\section{Characteristics of studied population}

121 patients participated in the study, 38\% of whom were women. The characteristics of the studied population are shown in Table I.

\section{WYNIKI BADAŃ}

\section{Charakterystyka badanej populacji}

W badaniu wzięło udział 121 chorych, w tym 38\% stanowiły kobiety. Charakterystykę badanej populacji przedstawiono w tabeli I.

Table I. Characteristics of studied population of haemodialysis patients Tabela I. Charakterystyka badanej populacji chorych hemodializowanych

\begin{tabular}{|c|c|c|c|c|}
\hline \multirow[t]{2}{*}{ Feature/Cecha } & \multicolumn{2}{|c|}{$\begin{array}{c}\text { Group with hyperphosphataemia/ } \\
\text { Grupa z hiperfosfatemią }\end{array}$} & \multicolumn{2}{|c|}{$\begin{array}{c}\text { Group with normophosphataemia/ } \\
\text { Grupa z normofosfatemią }\end{array}$} \\
\hline & $\mathrm{n}(61)$ & $\%$ & $\mathrm{n}(60)$ & $\%$ \\
\hline \multicolumn{5}{|c|}{ Professional activity/Aktywność zawodowa } \\
\hline Working/Pracujący & 9 & 15 & 5 & 8 \\
\hline Unemployed/Bezrobotny & 2 & 3 & 2 & 3 \\
\hline Pensioner/Emeryt & 15 & 25 & 36 & 61 \\
\hline Disability pensioner/Rencista & 35 & 57 & 17 & 28 \\
\hline \multicolumn{5}{|l|}{ Education/Wykształcenie } \\
\hline Primary/Podstawowe & 5 & 8 & 12 & 20 \\
\hline Vocational/Zawodowe & 22 & 36 & 22 & 36 \\
\hline Secondary/Średnie & 26 & 43 & 16 & 27 \\
\hline Higher/Wyższe & 8 & 13 & 10 & 17 \\
\hline
\end{tabular}

\begin{tabular}{lccc}
\hline $\begin{array}{c}\text { Duration of renal replacement therapy } \\
\text { declared by patients/Deklarowany } \\
\text { przez chorych czas trwania leczenia } \\
\text { nerkozastępczego }\end{array}$ & $\begin{array}{c}\text { Group with hyperphosphataemia/ } \\
\text { Grupa z hiperfosfatemią }\end{array}$ & $\begin{array}{c}\text { Group with normophosphataemia/ } \\
\text { Grupa z normofosfatemią }\end{array}$ & \% \\
\cline { 2 - 4 } & $\mathrm{n}(61)$ & 39 & 25 \\
\hline 0 to 5 years/Od 0 do 5 lat & 24 & 43 & 23 \\
More than 5 to 10 years/Ponad 5 do 10 lat & 11 & 18 & 12 \\
More than 10 years/Ponad 10 lat & 26 & 38 \\
\hline
\end{tabular}

\begin{tabular}{lcccc}
\hline Treatment duration/Czas leczenia & $0-5$ years/lat & $5-10$ years/lat & $>10$ years/lat & $p$ \\
Median value/Mediana & $7(4-12)$ & $11(6-14)$ & $12(9-17)$ & 0.0104 \\
\hline
\end{tabular}

Kruskal-Wallis test: median value (lower quartile - upper quartile)/test Kruskala-Wallisa: mediana (dolny kwartyl - górny kwartyl)

\section{Respondents' knowledge concerning dietary recommendations used in prevention of hyperphosphataemia}

Although more than $70 \%$ of patients in the group with hyperphosphataemia were aware of the necessity to limit the consumption of products with high phosphorus content, the respondents had problems choosing the recommended products.

Out of the meat sets presented in the survey, the following are recommended: beef, pork loin, chicken. Such a set was selected by $25 \%$ of respondents. $10 \%$ considered duck, turkey and goose to be safe. Giblets, smoked meat and fish were indicated by $3 \%$ of respondents. It is worth noting that as many as $62 \%$ of respondents admitted that they did not know which set was recommended for patients with hyperphosphataemia.

$56 \%$ were not aware of which dairy products are recommended for patients undergoing renal replacement therapy. $11 \%$ considered that there was no need to introduce any restrictions in this respect, while $10 \%$ of patients considered dairy products to be strictly forbidden. Only

\section{Wiedza badanych na temat zaleceń dietetycznych stosowanych w zapobieganiu hiperfosfatemii oraz normofosfatemii}

Mimo iż ponad $70 \%$ chorych w grupie $\mathbf{z}$ hiperfosfatemią było świadomych konieczności stosowania ograniczeń w spożywaniu produktów z wysoką zawartością fosforu, to respondenci ci mieli problemy $\mathrm{z}$ wyborem zalecanych produktów.

$\mathrm{Z}$ prezentowanych $\mathrm{w}$ ankiecie zestawów mięs zalecane są: wołowina, schab, kurczak. Takie właśnie odpowiedzi udzieliło $25 \%$ badanych, $10 \%$ za bezpieczne uznało kaczkę, indyka i gęś, a podroby, wędzone mięso i ryby zaznaczyło $3 \%$ respondentów. Na uwage zasługuje fakt, że aż $62 \%$ badanych przyznało się do braku wiedzy na temat zestawu zalecanego dla chorych z hiperfosfatemią.

$56 \%$ nie było świadomych, które produkty mleczne są bezpieczne dla chorych leczonych nerkozastępczo. $11 \%$ uważało, iż nie ma potrzeby stosowania jakichkolwiek ograniczeń w tym zakresie, natomiast $10 \%$ chorych uznało nabiał za bezwzględnie zakazany. Zale- 
$23 \%$ of respondents stated that dairy products, i.e. kefir, yoghurt, buttermilk or milk can be safely consumed up to one glass a day.

The necessity to reduce the consumption to one egg yolk per week was noticed by $34 \%$ of respondents. $3 \%$ of respondents believed that a minimum of one egg per day should be consumed, $7 \%$ limited the consumption of chicken egg white, but not yolk, and $56 \%$ of respondents did not know the answer to the posed question.

The largest number of correct answers was observed for the recommendations concerning cheeses. $64 \%$ of respondents considered that of all the cheese types, both cottage cheese and curd cheese are safe. Only $2 \%$ stated that hard and blue cheese should be consumed and 34\% of patients declared that they did not know the correct answer.

The studied patients had a problem indicating the bakery product with the lowest phosphate content. Only $28 \%$ of respondents knew that the lowest phosphate content was found in white wheat, sliced and rye bread. $7 \%$ of respondents indicated that soya bread or pumpernickel should be chosen, and $65 \%$ of patients did not know what assortment of products to choose.

Merely $28 \%$ were aware that the only allowed sweets were cakes with a low content of baking powder and chocolate-free cream wafers.

$49 \%$ of the studied patients confirmed that carbonated beverages such as Coca-Cola, Fanta and beer should be eliminated from the diet. $61 \%$ were aware that food rich in preservatives is a very rich source of phosphorus.

In the group of patients with normophosphataemia, $48 \%$ of the respondents chose a safe set of meats. Only $7 \%$ considered it appropriate to eat duck, goose, turkey, but as many as $45 \%$ of respondents said they did not know the answer to the posed question.

In the group of patients with normophosphataemia, awareness regarding the consumption of dairy products was much higher than in the group of patients with hyperphosphataemia. Only $35 \%$ of respondents did not know the answer. $7 \%$ of respondents declared that there is no need to introduce any restrictions, while 3\% of respondents considered dairy products to be strictly forbidden. More than half of the respondents, namely $55 \%$, stated that dairy products can be safely consumed up to one glass a day.

The necessity to limit the consumption of egg yolk to just one per week was noticed in the group with normophosphataemia by $58 \%$ of respondents, while $5 \%$ considered that at least one egg per day should be consumed. $12 \%$ limited the chicken egg white, but not yolk consumption, and $25 \%$ of patients did not know the recommendations for egg consumption with respect to hyperphosphataemia.

A higher percentage of correct answers was also reported for the recommendations concerning cheeses: $88 \%$ of those surveyed considered that of all cheese types, both cottage cheese and curd cheese are safe. Just 12\% of them did not know the correct answer.

The studied patients, similar to patients with hyperphosphataemia, had a big problem indicating the type dwie $23 \%$ badanych stwierdziło, iż produkty mleczne, takie jak kefir, jogurt, maślanka czy mleko, można bezpiecznie spożywać w ilości do jednej szklanki dziennie. Konieczność ograniczenia spożycia żółtka jaja do jednego $\mathrm{w}$ tygodniu dostrzegło $34 \% \mathrm{z}$ badanych respondentów, 3\% osób uważało, że należy spożywać minimum jedno jajko dziennie, 7\% stosowało ograniczenie w stosunku do spożycia białka jaja kurzego, ale nie żółtka, natomiast $56 \%$ badanych nie znało odpowiedzi na zadane pytanie.

Najwięcej poprawnych odpowiedzi odnotowano w przypadku zaleceń dotyczących serów. 64\% badanych uznało, że ze wszystkich gatunków bezpieczny jest ser typu grani oraz twarożek, tylko $2 \%$ stwierdziło, że należy spożywać ser żółty i pleśniowy, a 34\% chorych nie znało poprawnej odpowiedzi.

Badani chorzy mieli problem ze wskazaniem rodzaju pieczywa zawierającego najmniej fosforanów. Zaledwie $28 \%$ respondentów wiedziało, że najmniej tego pierwiastka zawiera pieczywo jasne pszenne, tostowe, żytnie. 7\% ankietowanych wskazało, że należy wybierać pieczywo sojowe lub pumpernikiel, a $65 \%$ chorych nie wiedziało, jaki asortyment produktów wybrać.

Zaledwie $28 \%$ miało świadomość, że jedynymi dozwolonymi słodyczami są ciasta $\mathrm{z}$ niską zawartością proszku do pieczenia oraz wafelki śmietankowe bez czekolady.

$49 \%$ z badanych pacjentów potwierdziło, że należy wykluczyć z jadłospisu napoje gazowane typu Coca-Cola, Fanta oraz piwo. 61\% było świadomych, że żywność bogata w konserwanty stanowi bardzo obfite źródło fosforu.

W grupie chorych $\mathrm{z}$ normofosfatemia bezpieczny zestaw mięs wybrało $48 \%$ badanych. Tylko $7 \%$ uznało za właściwe spożywanie kaczki, gęsi, indyka, przy czym aż $45 \%$ ankietowanych przyznało, że nie zna odpowiedzi na zadane pytanie.

W grupie pacjentów z normofosfatemia świadomość odnośnie do spożycia produktów mlecznych była zdecydowanie większa niż w grupie chorych z hiperfosfatemią. Odpowiedzi na pytania nie znało zaledwie 35\% badanych. $7 \%$ respondentów stwierdziło, iż nie ma potrzeby stosowania jakichkolwiek ograniczeń, natomiast 3\% uznało nabiał za bezwzględnie zakazany. Według ponad połowy badanych $(55 \%)$ produkty mleczne można bezpiecznie spożywać w ilości do jednej szklanki dziennie.

Konieczność ograniczenia spożycia żółtka jaj do jednego $\mathrm{w}$ tygodniu dostrzegło $\mathrm{w}$ grupie $\mathrm{z}$ normofosfatemią już 58\% badanych, 5\% uznało, że należy spożywać minimum jedno jajo dziennie. $12 \%$ stosowało ograniczenie w stosunku do białka jaja kurzego, a nie żółtka, a $25 \%$ chorych nie znało zaleceń dotyczących spożywania jaj w aspekcie hiperfosfatemii.

Badani pacjenci, podobnie jak chorzy z hiperfosfatemią, mieli duży problem ze wskazaniem rodzaju pieczywa zawierającego najmniej fosforanów. Zaledwie $24 \%$ badanych wiedziało, że najmniej fosforu zawiera pieczywo jasne pszenne, tostowe, żytnie. 3\% ankietowanych wskazało, że należy wybierać pieczywo so- 
of bread with the lowest phosphate content. Only 24\% of respondents knew that the lowest phosphate content was found in white wheat, sliced and rye bread. $3 \%$ of respondents indicated that soya bread or pumpernickel should be chosen, $3 \%$ pointed to crispbread and sunflower seed bread as safe, and as many as $70 \%$ of respondents did not know what to choose.

Merely $27 \%$ of respondents were aware that the only allowed sweets were cakes with low content of baking powder and chocolate-free cream wafers.

$72 \%$ of respondents confirmed that carbonated beverages such as Coca-Cola, Fanta, beer should be eliminated from the diet and as much as $77 \%$ was aware that foods rich in preservatives is a very rich source of phosphorus.

In most of the raised issues, the percentage of correct answers was significantly higher in patients with normophosphataemia than in those with hyperphosphataemia (Fig. 1, Tab.II). jowe lub pumpernikiel, 3\% uznało za bezpieczne pieczywo chrupkie, słonecznikowe, przy czym aż 70\% respondentów nie wiedziało, jakiego dokonać wyboru. Zaledwie $27 \%$ badanych miało świadomość, że jedynymi dozwolonymi słodyczami są ciasta $\mathrm{z}$ niską zawartością proszku do pieczenia, oraz wafelki śmietankowe bez czekolady.

$72 \%$ badanych potwierdziło konieczność wykluczenia $\mathrm{z}$ jadłospisu napojów gazowanych typu Coca-Cola, Fanta oraz piwo, poza tym aż $77 \%$ było świadomych, że żywność bogata w konserwanty stanowi bardzo obfite źródło fosforu.

W większości poruszanych zagadnień odsetek poprawnych odpowiedzi był istotnie większy u chorych z normofosfatemią niż z hiperfosfatemią (ryc. 1, tab. II).

Wiedza na temat zaleceń dietetycznych w zapobieganiu hiperfosfatemii była porównywalna wśród kobiet i mężczyzn (tab. III).

Nie stwierdzono wpływu czasu leczenia nerkozastępczego na wiedzę na temat podstawowych zaleceń dietetycznych w zapobieganiu hiperfosfatemii (tab. IV).

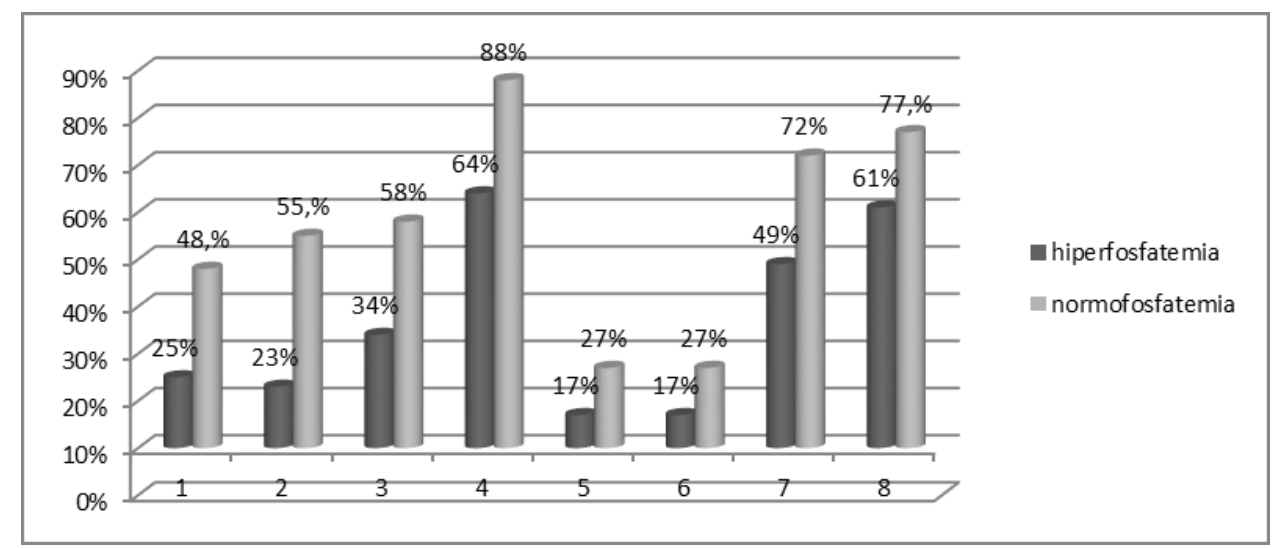

Key: 1 - meat selection, 2 - dairy products, 3 - egg consumption, 4 - cheese selection, 5 - bread selection, 6 -sweets selection, 7 - avoiding carbonated beverages, 8 - avoiding preservatives/Legenda: 1 - dobór mięs, 2 - produkty mleczne, 3 - spożycie jaj, 4 - dobór serów, 5 - dobór pieczywa, 6 - dobór słodyczy, 7 - unikanie napojów gazowanych, 8 - unikanie konserwantów

Fig. 1. List of correct answers obtained in both groups.

Ryc. 1. Zestawienie poprawnych odpowiedzi uzyskanych w obu grupach.

Table II. Respondents' knowledge concerning basic dietary recommendations used to prevent hyperphosphataemia Tabela II. Wiedza badanych na temat podstawowych zaleceń dietetycznych stosowanych w zapobieganiu hiperfosfatemii

\begin{tabular}{|c|c|c|c|c|c|c|}
\hline \multirow{2}{*}{$\begin{array}{l}\text { Recommended dietary recommendations (correct } \\
\text { survey responses)/Zalecane wskazówki dietetyczne } \\
\text { (poprawne odpowiedzi ankietowe) }\end{array}$} & \multicolumn{2}{|c|}{$\begin{array}{l}\text { Group with } \\
\text { hyperphosphataemia/ } \\
\text { Grupa z hiperfosfatemią }\end{array}$} & \multicolumn{2}{|c|}{$\begin{array}{c}\text { Group with } \\
\text { normophosphataemia/ } \\
\text { Grupa z normofosfatemią }\end{array}$} & \multirow[t]{2}{*}{$\mathrm{P}^{*} \mathrm{Ch} \mathbf{i}^{2}$} & \multirow[t]{2}{*}{ P*Fisher's } \\
\hline & $n=61$ & $\%$ & $n=60$ & $\%$ & & \\
\hline 1 & 2 & 3 & 4 & 5 & 6 & 7 \\
\hline $\begin{array}{l}\text { Composing meals by selecting meat such as beef, chicken, } \\
\text { pork loin/Komponowanie posiłków - wybór mięs, takich jak } \\
\text { wołowina, kurczak, schab }\end{array}$ & 15 & 25 & 29 & 48 & 0.0066 & 0.0083 \\
\hline $\begin{array}{l}\text { Consumption of milk, buttermilk, yoghurts interchangeably } \\
\text { up to one glass a day/Spożywanie mleka, maślanki, } \\
\text { jogurtów zamiennie do szklanki dziennie }\end{array}$ & 14 & 23 & 33 & 55 & 0.0003 & 0.0004 \\
\hline $\begin{array}{l}\text { Unlimited consumption of chicken egg white and egg yolk } \\
\text { consumption limited to one per week/Spożywanie białka jaja } \\
\text { kurzego bez ograniczeń, natomiast ograniczenie żółtka jaj } \\
\text { do jednego tygodniowo }\end{array}$ & 21 & 34 & 35 & 58 & 0.0084 & 0.0108 \\
\hline
\end{tabular}


cd. tab. II

\begin{tabular}{|c|c|c|c|c|c|c|}
\hline 1 & 2 & 3 & 4 & 5 & 6 & 7 \\
\hline $\begin{array}{l}\text { Out of the cheeses available on the market, selecting } \\
\text { cottage cheese, curd cheese/Z dostępnych na rynku serów } \\
\text { wybór produktów typu grani, ser twarogowy }\end{array}$ & 39 & 64 & 53 & 88 & 0.0017 & 0.0025 \\
\hline $\begin{array}{l}\text { Preferred white wheat, sliced or rye bread/Preferowane } \\
\text { pieczywo jasne pszenne, tostowe lub żytnie }\end{array}$ & 17 & 28 & 14 & 24 & NS & NS \\
\hline $\begin{array}{l}\text { Selecting sweets without chocolate such as cream wafers, } \\
\text { cakes with small amount of baking powder/Wybór słodyczy } \\
\text { bez czekolady, tj. wafelki śmietankowe, ciasta } \\
\text { z niewielką ilościa proszku do pieczenia }\end{array}$ & 17 & 28 & 16 & 27 & NS & NS \\
\hline $\begin{array}{l}\text { Avoiding carbonated beverages such as Fanta, Coca-Cola, } \\
\text { beer/Unikanie napojów gazowanych, tj. Fanta, Coca-cola, } \\
\text { piwo }\end{array}$ & 30 & 49 & 43 & 72 & 0.015 & 0.0156 \\
\hline $\begin{array}{l}\text { Avoiding foods rich in preservatives, canned and smoked } \\
\text { foods/Unikanie żywności bogatej w konserwanty }\end{array}$ & 37 & 61 & 46 & 77 & NS & NS \\
\hline
\end{tabular}

Table III. Respondents' knowledge concerning basic dietary recommendations used to prevent hyperphosphataemia by gender Tabela III. Wiedza badanych na temat podstawowych zaleceń dietetycznych stosowanych w zapobieganiu hiperfosfatemii z podziałem na płeć

\begin{tabular}{|c|c|c|c|c|c|c|}
\hline \multirow{2}{*}{ Dietary recommendations/Zalecane wskazówki dietetyczne } & \multicolumn{2}{|c|}{ Men/Mężczyźni } & \multicolumn{2}{|c|}{ Women/Kobiety } & \multirow{2}{*}{$\mathrm{P}^{*} \mathrm{Chi}^{2}$} & \multirow{2}{*}{ P*Fisher's } \\
\hline & $n=74$ & $\%$ & $n=47$ & $\%$ & & \\
\hline $\begin{array}{l}\text { Composing meals by selecting meat such as beef, chicken, pork loin/ } \\
\text { Komponowanie posiłków - wybór mięs takich, jak wołowina kurczak, } \\
\text { schab }\end{array}$ & 25 & 34 & 19 & 40 & NS & NS \\
\hline $\begin{array}{l}\text { Consumption of milk, buttermilk, yoghurts interchangeably up to one } \\
\text { glass a day/Spożywanie mleka, maślanki, jogurtów zamiennie do } \\
\text { szklanki dziennie }\end{array}$ & 26 & 35 & 21 & 45 & NS & NS \\
\hline $\begin{array}{l}\text { Unlimited consumption of chicken egg white and egg yolk consumption } \\
\text { limited to one per week/Spożywanie białka jaja kurzego bez ograniczeń, } \\
\text { natomiast ograniczenie żółtka jaj do jednego tygodniowo }\end{array}$ & 32 & 43 & 24 & 51 & NS & NS \\
\hline $\begin{array}{l}\text { Selecting cottage cheese, curd cheese/Wybór serka typu grani, sera } \\
\text { twarogowego }\end{array}$ & 53 & 72 & 39 & 83 & NS & NS \\
\hline $\begin{array}{l}\text { Preferred white wheat, sliced or rye bread/Preferowane pieczywo jasne } \\
\text { pszenne, tostowe lub żytnie }\end{array}$ & 18 & 24 & 13 & 28 & NS & NS \\
\hline $\begin{array}{l}\text { Selecting sweets without chocolate such as cream wafers, cakes with } \\
\text { small amount of baking powder/Wybór słodyczy bez czekolady, tj., } \\
\text { wafelki śmietankowe, ciasta z niewielka ilościa proszku do pieczenia }\end{array}$ & 22 & 30 & 11 & 23 & NS & NS \\
\hline $\begin{array}{l}\text { Avoiding carbonated beverages such as Fanta, Coca-Cola, beer/ } \\
\text { Unikanie napojów gazowanych, jak Fanta, Coca-cola, piwo }\end{array}$ & 45 & 61 & 28 & 60 & NS & NS \\
\hline $\begin{array}{l}\text { Avoiding foods rich in preservatives, canned and smoked foods/Unikanie } \\
\text { żywności bogatej w konserwanty, konserw oraz żywności wędzonej }\end{array}$ & 51 & 69 & 32 & 68 & NS & NS \\
\hline
\end{tabular}

* Dependent variable: gender - chi2/Fisher's test/Zmienna zależna: pleć - test Chi²/Fishera

Tabela IV. Respondents' knowledge concerning basic dietary recommendations used to prevent hyperphosphataemia depending on duration of renal replacement therapy

Tabela IV. Wiedza badanych na temat podstawowych zaleceń dietetycznych stosowanych w zapobieganiu hiperfosfatemii z uwzględnieniem czasu trwania leczenia nerkozastępczego

\begin{tabular}{|c|c|c|c|c|c|c|c|c|}
\hline \multirow{2}{*}{ Dietary recommendations/Zalecane wskazówki dietetyczne } & \multicolumn{2}{|c|}{$0-5$ years/lat } & \multicolumn{2}{|c|}{$>5-10$ years/lat } & \multicolumn{2}{|c|}{$>10$ years/lat } & \multirow{2}{*}{$\mathrm{P}^{*} \mathrm{Chi}^{2}$} & \multirow{2}{*}{ P*Fisher's } \\
\hline & $\mathrm{n}$ & $\%$ & $\mathrm{n}$ & $\%$ & $\mathrm{n}$ & $\%$ & & \\
\hline 1 & 2 & 3 & 4 & 5 & 6 & 7 & 8 & 0 \\
\hline $\begin{array}{l}\text { Composing meals by selecting meat such as beef, chicken, pork } \\
\text { loin/Komponowanie posiłków - wybór mięs, takich jak wołowina } \\
\text { kurczak, schab }\end{array}$ & 13 & 27 & 19 & 39 & 12 & 52 & NS & NS \\
\hline $\begin{array}{l}\text { Consumption of milk, buttermilk, yoghurts interchangeably } \\
\text { up to one glass a day/Spożywanie mleka, maślanki, jogurtów } \\
\text { zamiennie do szklanki dziennie }\end{array}$ & 17 & 35 & 19 & 39 & 11 & 48 & NS & NS \\
\hline $\begin{array}{l}\text { Unlimited consumption of chicken egg white and egg yolk } \\
\text { consumption limited to one per week/Spożywanie białka jaja } \\
\text { kurzego bez ograniczeń, natomiast ograniczenie żółtka jaj do } \\
\text { jednego tygodniowo }\end{array}$ & 19 & 38 & 24 & 49 & 13 & 56 & NS & NS \\
\hline
\end{tabular}




\begin{tabular}{|c|c|c|c|c|c|c|c|c|}
\hline 1 & 2 & 3 & 4 & 5 & 6 & 7 & 8 & $\frac{\text { d. tah }}{9}$ \\
\hline $\begin{array}{l}\text { Selecting cottage cheese, curd cheese/Wybór serka typu grani, } \\
\text { sera twarogowego }\end{array}$ & 34 & 70 & 39 & 80 & 19 & 83 & NS & NS \\
\hline $\begin{array}{l}\text { Preferred white wheat, toast or rye bread/Preferowane pieczywo } \\
\text { jasne pszenne, tostowe lub żytnie }\end{array}$ & 11 & 22 & 16 & 33 & 6 & 27 & NS & NS \\
\hline $\begin{array}{l}\text { Selecting sweets without chocolate such as cream wafers, } \\
\text { cakes with a small amount of baking powder/Wybór słodyczy } \\
\text { bez czekolady, tj. wafelki śmietankowe, ciasta z niewielką ilością } \\
\text { proszku do pieczenia }\end{array}$ & 11 & 22 & 16 & 33 & 6 & 27 & NS & NS \\
\hline $\begin{array}{l}\text { Avoiding carbonated beverages such as Fanta, Coca-Cola, } \\
\text { beer/Unikanie napojów gazowanych, tj. Fanta, Coca-cola, piwo }\end{array}$ & 27 & 55 & 32 & 65 & 14 & 61 & NS & NS \\
\hline $\begin{array}{l}\text { Avoiding foods rich in preservatives, canned and smoked } \\
\text { foods/Unikanie żywności bogatej w konserwanty, konserw oraz } \\
\text { żywności wędzonej }\end{array}$ & 33 & 67 & 33 & 67 & 17 & 74 & NS & NS \\
\hline
\end{tabular}

* Dependent variable - duration of treatment - chi²/Fisher's test/Zmienna zależna - czas trwania leczenia - test Chi/Fishera

The knowledge concerning dietary recommendations in the prevention of hyperphosphataemia was comparable among men and women (Tab. III).

There was no effect of the duration of renal replacement therapy on the knowledge of basic dietary recommendations in the prevention of hyperphosphataemia (Tab. IV).

\section{Respondents' knowledge concerning use of phosp- hate binders}

The vast majority of patients admitted that they regularly took preparations binding phosphorus in the gastrointestinal tract; $83 \%$ of respondents took calcium carbonate, $3 \%$ of patients took calcium acetate, while $7 \%$ of respondents took calcium supplements with vitamin $\mathrm{D}$ and $7 \%$ admitted that they did not use any medication binding phosphorus in the gastrointestinal tract (Tab. V).

Preparations binding phosphorus in the gastrointestinal tract reduce the absorption of phosphates only when taken with the first bite of a meal. Such an answer was

\section{Wiedza badanych na temat stosowania leków wią- żących fosfor}

Zdecydowana większość chorych regularnie przyjmowała preparaty wiążące fosfor w przewodzie pokarmowym, w tym: $83 \%$ badanych stosowało węglan wapnia, $3 \%$ chorych octan wapnia, natomiast $7 \%$ ankietowanych zażywało suplementy wapnia w składzie z wit. D. $7 \%$ badanych nie stosowało żadnego środka mającego na celu wiązanie fosforu $\mathrm{w}$ przewodzie pokarmowym (tab. V).

Preparaty wiążace fosfor w przewodzie pokarmowym zmniejszają wchłanianie fosforanów jedynie wtedy, gdy są zażywane wraz z pierwszym kęsem posiłku. Takiej odpowiedzi udzieliło $67 \%$ badanych, zaś $8 \%$ respondentów uznało za zasadne łączenie wiązaczy fosforu $\mathrm{z}$ innymi lekami, a zdaniem 3\% respondentów sposób zażywania leków nie miał wpływu na ich działanie.

$5 \%$ badanych było przekonanych, że preparaty wiążące fosfor należy spożywać po posiłku, natomiast $17 \%$ nie potrafiło wskazać sposobu zażywania leków wiążących fosfor w przewodzie pokarmowym (tab. VI).

Table V. Use of preparations binding phosphorus in the gastrointestinal tract Tabela V. Stosowanie preparatów wiążących fosfor w przewodzie pokarmowym

\begin{tabular}{|c|c|c|c|c|}
\hline \multirow{2}{*}{$\begin{array}{l}\text { Preparation used to bind phosphorus } \\
\text { in the gastrointestinal tract/Preparat } \\
\text { stosowany w celu wiązania fosforu } \\
\text { w przewodzie pokarmowym }\end{array}$} & \multicolumn{2}{|c|}{$\begin{array}{c}\text { Group with hyperphosphataemia/ } \\
\text { Grupa z hiperfosfatemią }\end{array}$} & \multicolumn{2}{|c|}{$\begin{array}{c}\text { Group with normophosphataemia/ } \\
\text { Grupa z normofosfatemią }\end{array}$} \\
\hline & $\mathrm{n}=61$ & $\%$ & $\mathrm{n}=60$ & $\%$ \\
\hline Calcium carbonate/Węglan wapnia & 48 & 79 & 53 & 89 \\
\hline Calcium acetate/Octan wapnia & 2 & 3 & 2 & 3 \\
\hline $\begin{array}{l}\text { Calcium supplement with vit. D/Suplement } \\
\text { wapnia z wit. D w składzie }\end{array}$ & 5 & 8 & 3 & 5 \\
\hline $\begin{array}{l}\text { Non-calcium-based medications/Leki } \\
\text { niewapniowe }\end{array}$ & 0 & 0 & 0 & 0 \\
\hline $\begin{array}{l}\text { Declaration of not using any of above listed } \\
\text { substances/Deklaracja niestosowania } \\
\text { żadnego z podanych środków }\end{array}$ & 6 & 10 & 2 & 3 \\
\hline
\end{tabular}




\begin{tabular}{|c|c|c|c|c|c|c|c|c|}
\hline \multirow[t]{2}{*}{ Dietary recommendations/Zalecane wskazówki dietetyczne } & \multicolumn{2}{|c|}{$0-5$ years/lat } & \multicolumn{2}{|c|}{$\begin{array}{l}>5-10 \\
\text { years/lat }\end{array}$} & \multicolumn{2}{|c|}{$>10$ years/lat } & \multirow[t]{2}{*}{$\mathrm{P}^{*} \mathrm{Chi}^{2}$} & \multirow[t]{2}{*}{ P*Fisher's } \\
\hline & $\mathrm{n}$ & $\%$ & $\mathrm{n}$ & $\%$ & $\mathrm{n}$ & $\%$ & & \\
\hline $\begin{array}{l}\text { Composing meals by selecting meat such as beef, chicken, pork } \\
\text { loin/Komponowanie posiłków - wybór mięs, takich jak wołowina } \\
\text { kurczak, schab }\end{array}$ & 13 & 27 & 19 & 39 & 12 & 52 & NS & NS \\
\hline $\begin{array}{l}\text { Consumption of milk, buttermilk, yoghurts interchangeably } \\
\text { up to one glass a day/Spożywanie mleka, maślanki, jogurtów } \\
\text { zamiennie do szklanki dziennie }\end{array}$ & 17 & 35 & 19 & 39 & 11 & 48 & NS & NS \\
\hline $\begin{array}{l}\text { Unlimited consumption of chicken egg white and egg yolk } \\
\text { consumption limited to one per week/Spożywanie białka jaja } \\
\text { kurzego bez ograniczeń, natomiast ograniczenie żółka jaj do } \\
\text { jednego tygodniowo }\end{array}$ & 19 & 38 & 24 & 49 & 13 & 56 & NS & NS \\
\hline $\begin{array}{l}\text { Selecting cottage cheese, curd cheese/Wybór serka typu grani, } \\
\text { sera twarogowego }\end{array}$ & 34 & 70 & 39 & 80 & 19 & 83 & NS & NS \\
\hline $\begin{array}{l}\text { Preferred white wheat, toast or rye bread/Preferowane pieczywo } \\
\text { jasne pszenne, tostowe lub żytnie }\end{array}$ & 11 & 22 & 16 & 33 & 6 & 27 & NS & NS \\
\hline $\begin{array}{l}\text { Selecting sweets without chocolate such ascream wafers, cakes } \\
\text { with a small amount of baking powder/Wybór słodyczy bez } \\
\text { czekolady, tj. wafelki śmietankowe, ciasta z niewielką ilością } \\
\text { proszku do pieczenia }\end{array}$ & 11 & 22 & 16 & 33 & 6 & 27 & NS & NS \\
\hline $\begin{array}{l}\text { Avoiding carbonated beverages such as Fanta, Coca-Cola, beer/ } \\
\text { Unikanie napojów gazowanych, tj. Fanta, Coca-cola, piwo }\end{array}$ & 27 & 55 & 32 & 65 & 14 & 61 & NS & NS \\
\hline $\begin{array}{l}\text { Avoiding foods rich in preservatives, canned and smoked } \\
\text { foods/Unikanie żywności bogatej w konserwanty, konserw oraz } \\
\text { żywności wędzonej }\end{array}$ & 33 & 67 & 33 & 67 & 17 & 74 & NS & NS \\
\hline
\end{tabular}

* Dependent variable - duration of treatment - chi²/Fisher's test/Zmienna zależna - czas trwania leczenia - test Chi/Fishera

provided by $67 \%$ of respondents, while $8 \%$ of them considered it appropriate to combine phosphorus binders with other drugs, and in the opinion of $3 \%$ of respondents the way they used the medicine did not affect their performance.

$5 \%$ of respondents were convinced that phosphate binders should be taken after meal, while $17 \%$ were unable to indicate how to take preparations binding phosphorus in the gastrointestinal tract (Tab. VI).

\section{DISCUSSION}

Phosphorus is an element contained in food products, both of plant and animal origin. In a healthy person, the serum phosphate concentration is usually within normal limits [7]. Deteriorating glomerular filtration results in an increased serum phosphorus concentration [8]. The factors that contribute to the incidence of cardiovascular complications are not only hypertension or diabetes mellitus, but also irregularities in calcium-phosphate metabolism. There is a positive correlation between hyperphosphataemia ( $>5 \mathrm{mg} / \mathrm{dl}$ ), hypercalcemia $(>9.5 \mathrm{mg} / \mathrm{dl})$ and increased mortality in haemodialysis patients. Hyperphosphataemia contributes to tissue calcification, which significantly accelerates the ageing process of blood vessels $[8,11]$. This subject seems particularly relevant in the light of reports that hyperphosphataemia increases the risk of death in ha-

\section{DYSKUSJA}

Fosfor jest pierwiastkiem obecnym w produktach żywnościowych zarówno pochodzenia roślinnego, jak i zwierzęcego. U zdrowego człowieka stężenie fosforanów w surowicy utrzymuje się zazwyczaj w granicach normy [7]. Pogarszająca się filtracja kłębuszkowa skutkuje zwiększonym stężeniem fosforu w surowicy [8]. Czynnikami sprzyjającymi występowaniu powikłań sercowo-naczyniowych są nie tylko nadciśnienie tętnicze czy cukrzyca, lecz także nieprawidłowości w zakresie gospodarki wapniowo-fosforanowej. Istnieje dodatnia korelacja pomiędzy hiperfosfatemią ( $>5 \mathrm{mg}$ / $\mathrm{dl}$ ), hiperkalcemią ( $>9,5 \mathrm{mg} / \mathrm{dl})$ a zwiększoną śmiertelnością wśród hemodializowanych chorych. Hiperfosfatemia sprzyja kalcyfikacji tkanek, co znacznie przyspiesza proces starzenia się naczyń krwionośnych $[8,11]$. Tematyka ta wydaje się szczególnie istotna w świetle doniesień, że hiperfosfatemia zwiększa ryzyko zgonu u hemodializowanych chorych średnio o $12 \%$, przy jednoczesnym występowaniu hiperkalcemii i zwiększeniu stężenia PTH o ponad 17\% [10].

\section{Wpływ diety i preparatów wiążących fosfor na stężenie fosforu w surowicy}

W leczeniu chorych na PChN istotne znaczenie odgrywa postępowanie dietetyczne. Wskazane jest monitorowanie wielu składników odżywczych i stosowanie 
emodialysis patients on average by $12 \%$, and together with hypercalcemia and an elevated PTH concentration by over $17 \%[10]$.

\section{Influence of diet and phosphate binders on serum phosphorus concentration}

Dietary management plays an important role in the treatment of CKD patients. It is advisable to monitor a number of nutrients and to follow specific recommendations. According to a study conducted by Judith Beto et al. in a group of 22989 dialysis patients, fewer complications and better nutritional status were observed in patients who regularly took drugs binding phosphorus in the gastrointestinal tract and controlled the quality of consumed meals. The study also revealed that the amount of absorbed phosphates depends on the use of food preservatives. The more the product was modified, the larger the amount of absorbed phosphorus was. Therefore, the quality of selected meals plays a significant role in preventing hyperphosphataemia [12,21]. It is difficult to remove excess phosphates during haemodialysis. The diet of a haemodialysis patient provides approximately 1200-1400 mg of phosphorus during the 48-hour break between haemodialysis procedures. A single dialysis session removes on average from 600 to $800 \mathrm{mg}$ of phosphorus; therefore, the recommendations regarding restrictions on the intake of this element are highly justified [13].

Unfortunately, as has been demonstrated, the subjects in both groups had problems selecting nutrients so as to compose a meal with a limited amount of phosphates. Due to the high phosphate content in food, a diet alone may not be sufficient. In order to restore the phosphate balance, it is usually necessary to apply substances binding phosphorus in the gastrointestinal tract and thus hinder its absorption. Phosphate binders administered orally together with food form insoluble complexes excreted by the digestive tract. However, an important element is how the medicine is taken administration. Taking them on an empty stomach or after a meal results in significant absorption of the preparation, while phosphorus binding is limited. To fully benefit from the action of the applied substance, it should be taken with the first bite of a meal [15].

The effectiveness of the applied drugs depends primarily on proper use of the preparation and its phosphorus binding strength. The following phosphate binders are currently available on the market: calcium carbonate and acetate, as well as non-calcium-based compounds, i.e. sevelamer hydrochloride and lactate carbonate. Calcium-based preparations may cause hypercalcaemia and result in tissue and vascular calcification; therefore it is advisable to monitor serum calcium levels during therapy. Aluminium preparations, though effective in reducing phosphorus absorption, may only constitute a short-term replacement therapy. Prolonged use of aluminium results in the accumulation of this element and the development of aluminium encephalopathy [14]. konkretnych zaleceń. Jak wynika z badań Judith Beto i wsp. przeprowadzonych w grupie 22989 chorych dializowanych, mniej powikłań i lepszy stan odżywienia obserwowano u pacjentów, którzy regularnie stosowali leki wiążące fosfor w przewodzie pokarmowym i kontrolowali jakość spożywanych posiłków. Badanie wykazało także, że ilość wchłanianych fosforanów jest zależna od stosowania środków konserwujących żywność. Im bardziej modyfikowany był produkt, tym większa była pula wchłanianego fosforu. Stąd też jakość dobieranych posiłków odgrywa istotne znaczenie w zapobieganiu hiperfosfatemii [12,21].

Usuwanie nadmiaru fosforanów podczas zabiegu hemodializy jest trudne. Dieta chorego hemodializowanego dostarcza średnio ok. 1200-1400 mg fosforu w ciągu 48 godzinnej przerwy pomiędzy zabiegami. Pojedyncza sesja dializacyjna usuwa natomiast średnio od 600 do $800 \mathrm{mg}$ fosforu, zatem zalecenia dotyczące ograniczeń w przyjmowaniu tego pierwiastka są jak najbardziej zasadne [13].

Niestety, jak wykazano, badani w obu grupach mieli problem z doborem składników pokarmowych tak, by skomponować posiłek z ograniczoną ilością fosforanów. Z uwagi na ich wysoką zawartość w pożywieniu samo zastosowanie diety może okazać się niewystarczające. Aby przywrócić równowagę fosforanową, zwykle wymagane jest zastosowanie środków wiążących fosfor w przewodzie pokarmowym i utrudniających tym samym jego wchłanianie. Związki te podawane doustnie wraz z pokarmem tworzą nierozpuszczalne kompleksy wydalane przewodem pokarmowym. Istotnym elementem jest jednak sposób przyjmowania leku. Przyjmowanie ich na czczo bądź po posiłku powoduje znaczne wchłanianie preparatu, natomiast wiązanie fosforu jest ograniczone. Aby w pełni wykorzystać działanie zastosowanego środka, należy go zażyć wraz z pierwszym kęsem posiłku [15].

Skuteczność stosowanych środków zależy przede wszystkim od właściwego zażywania preparatu oraz jego siły wiązania fosforu. Obecnie na rynku dostępne są następujące preparaty wiążące fosfor: węglan i octan wapnia oraz związki niewapniowe, tj. chlorowodorek sewelameru oraz węglan laktanu. Środki na bazie wapnia mogą powodować hiperkalcemię oraz skutkować kalcyfikacją tkanek i naczyń, stąd też podczas terapii wskazane jest monitorowanie stężenia wapnia w surowicy. Preparaty glinowe, mimo iż skutecznie zmniejszają wchłanianie fosforu, mogą stanowić tylko krótkotrwałą terapię zastępczą. Długotrwałe stosowanie glinu prowadzi do kumulowania się tego pierwiastka i rozwoju encefalopatii glinowej [14].

Badani z obu grup w zdecydowanej większości deklarowali zażywanie preparatów wiążących fosfor w przewodzie pokarmowym. Jedynie $10 \% \mathrm{z}$ nich nie przyjmowało żadnego $\mathrm{z}$ preparatów. Wiodącym środkiem był węglan wapnia, którego stosowanie deklarowało prawie $90 \%$ badanych $\mathrm{w}$ grupie $\mathrm{z}$ normofosfatemią i niecałe $80 \%$ chorych $z$ hiperfosfatemią. 
The vast majority of respondents from both groups declared the use of preparations binding phosphorus in the gastrointestinal tract. Only $10 \%$ of them did not take any of the preparations. The leading substance was calcium carbonate, the use of which was declared by almost $90 \%$ of patients with normophosphataemia and less than $80 \%$ of patients with hyperphosphataemia. The respondents were aware of the recommendations, however, significant differences observed between the groups are noteworthy. In the group of patients with normophosphataemia, three-quarters of the subjects knew how to use the preparations properly, whereas in the group with hyperphosphataemia only every second subject was tested, which could result in increased serum phosphorus concentrations.

\section{Use of dietary recommendations aimed at preventing hyperphosphataemia}

Maintaining a proper serum phosphorus concentration is closely related to an appropriate diet, the use of preparations binding phosphorus in the gastrointestinal tract and effective dialysis. The main objective of dietary treatment is a low phosphate intake (preferably up to $700 \mathrm{mg}$ /day) while maintaining an adequate protein intake [9].

Phosphorus is an element present in almost every kind of food. Inorganic phosphorus, which is primarily used as a food preservative, is often found in contemporary diets. Organic phosphorus is mainly present in protein products of plant and animal origin. It is worth noting that the presence of phytin casing in products of plant origin is responsible for the low bioavailability of phosphorus in these products $(20-40 \%)$, as opposed to phosphorus of animal origin, which is $40-60 \%$ absorbed. I On the other hand, inorganic phosphorus is absorbed $100 \%$, which is why its excessive consumption often leads to hyperphosphataemia [16].

It seems that highly processed food is a factor significantly hindering the maintenance of homeostasis in calcium-phosphate metabolism in patients with CKD [9]. The analysis showed that the most preservatives are present in soft drinks such as Coca-Cola, Fanta, etc. [16]. Current legislation obliges food producers to indicate on the label the agents used for preserving food products. In addition, the food labelling in Europe makes it easy to identify phosphate-containing preservatives, for example, the series from E 340 to 349 [16]. The role of education of CKD patients has been shown, among others, by Kalantar-Zadeh et al., who proved that educating patients in avoiding products with preservatives contributed to lowering the serum phosphate concentrations of these patients. Studies have revealed that patients undergoing education were much more likely to pay attention to the chemical composition of consumed food, with particular emphasis on food preservation agents [9].

In this study, the surveyed respondents were aware that modified products are a rich source of phosphorus. However, when analysing particular groups of respon-
Badani byli świadomi wskazanych zaleceń, aczkolwiek na uwagę zasługują zaobserwowane istotne różnice pomiędzy grupami. Wśród chorych z normofosfatemią trzy czwarte badanych wiedziało, jak właściwie stosować preparaty, natomiast $\mathrm{w}$ grupie $\mathrm{z}$ hiperfosfatemią już tylko co drugi badany, co mogło skutkować zwiększonymi stężeniami fosforu w surowicy.

\section{Zastosowanie wskazówek dietetycznych w celu zapobiegania hiperfosfatemii}

Utrzymanie właściwego stężenia fosforu w surowicy jest ściśle związane ze stosowaniem odpowiedniej diety, środków wiążących fosfor w przewodzie pokarmowym oraz efektywnej dializoterapii. Głównym celem leczenia dietetycznego jest małe spożycie fosforanów (najlepiej do $700 \mathrm{mg}$ /dobę) przy zachowaniu odpowiedniego spożycia białka [9].

Fosfor jest pierwiastkiem obecnym niemal w każdym rodzaju żywności. Fosfor nieorganiczny, występuje przede wszystkim jako dodatek konserwujący żywność, często spotykany we współczesnej diecie. Fosfor organiczny towarzyszy przede wszystkim produktom białkowym pochodzenia roślinnego i zwierzęcego. $\mathrm{Na}$ uwagę zasługuje fakt, że obecność osłonki fitynowej $\mathrm{w}$ produktach pochodzenia roślinnego odpowiada za małą biodostępność fosforu w tych produktach (20$-40 \%$ ), w odróżnieniu do fosforu pochodzenia zwierzęcego, który wchłaniania się w 40-60\%. Fosfor nieorganiczny wchłania się natomiast w $100 \%$, dlatego jego nadmierna konsumpcja często prowadzi do hiperfosfatemii [16].

Wydaje się, że czynnikiem istotnie utrudniającym chorym na PChN utrzymanie homeostaz w zakresie gospodarki wapniowo-fosforanowej jest bogato przetworzona żywność [9]. Analiza wykazała, że najwięcej środków konserwujących znajduje się w napojach bezalkoholowych, tj. Coca-coli, Fancie itp. [16]. Obecne przepisy zobowiązują producentów żywności do wypisania na etykietach środków użytych do konserwowania produktów żywnościowych. Oznakowanie żywności w Europie umożliwia łatwą identyfikację konserwantów zawierajacych fosforany - dotyczy to $\mathrm{np}$. serii od E 340 do 349 [16].

Rolę edukacji chorych na PChN wykazali m.in. Kalantar-Zadeh i wsp., którzy dowiedli, że edukacja chorych w zakresie unikania produktów $\mathrm{z}$ dodatkiem konserwantów przyczyniła się do obniżenia stężeń fosforanów w surowicy tych pacjentów. Badania wykazały, że przeszkoleni chorzy znacząco częściej zwracali uwagę na skład chemiczny spożywanych potraw, ze szczególnym uwzględnieniem środków stosowanych do konserwowania żywności [9].

W prezentowanej pracy badani respondenci byli świadomi, że produkty modyfikowane stanowią bogate źródło fosforu, przy czym analizując poszczególne grupy chorych można było zauważyć znacząco większy deficyt wiedzy właśnie u osób z zaburzeniami gospodarki wapniowo-fosforanowej. Połowa badanych z hiperfosfatemią była świadoma szkodliwości spoży- 
dents, a significantly larger knowledge deficit could be observed in the patients with calcium-phosphate disorders. Every second respondent with hyperphosphataemia was aware of the adverse effects of carbonated beverages, whereas in the group of patients with normophosphataemia three-quarters of the respondents already possessed this knowledge.

In the past, it was recommended to limit protein intake in order to compensate for hyperphosphataemia. Currently, it is well known that such management results in protein malnutrition, which significantly worsens the clinical condition of the patient. Contemporary dietary recommendations strive to encourage patients to consume protein products with a low phosphorus content and to avoid processed food with preservatives [9].

The analysis of food in terms of phosphate content presented by D'Alessandro et al. revealed that the highest amounts of phosphorus in food products are found in egg yolk, hard cheeses, nuts, some fish and meat [16]. Analysis of the amount of phosphorus (in milligrams) per gram of protein showed that protein products vary significantly in their phosphate content. It was concluded that protein products containing up to $12 \mathrm{mg}$ of phosphorus/1g of protein are the most beneficial for the health of CKD patients.

Taylor et al. suggested that egg white is a good source of protein with a high biological value and low phosphorus content $(<2 \mathrm{mg} / \mathrm{g})$. In a pilot study conducted among haemodialysis patients, meat was replaced with chicken egg white, which resulted in a reduced serum phosphate concentration while maintaining a proper albumin concentration [19]. In the group of patients with hyperphosphataemia, few respondents were aware of the fact that the consumption of chicken egg white is a "safe" source of protein; only one in three respondents gave the right answer. The respondents from the group with normophosphataemia showed better knowledge of the subject - over half of the respondents knew the issue.

Controlling the amount of phosphorus consumed on a daily basis is very difficult. An essential element is the provision of Constant dietary counselling in centres taking care of patients with chronic kidney disease is essential here. Patients need information concerning the phosphorus content of individual products. Therapeutic education should not be limited to informing patients about products they should avoid, but above all it should provide them with alternative solutions. D'Alessandro et al. presented a specially designed pyramid of foods recommended in the diet of hyperphosphataemic patients. It can be a useful tool in the work of a nurse $[16,17,18]$. The presented pyramid consists of six levels, which include food products from the smallest to the largest content of phosphates.

At the very bottom of the pyramid there are phosphorous-free ingredients, i.e. olive oil, egg white, vegetables and fruit. These products may be consumed without any restrictions. The only exception are diabetics because of the glucose content. Patients with hyperka- wania napojów gazowanych, natomiast wśród chorych z normofosfatemią już trzy czwarte grupy posiadało tę wiedzę.

W przeszłości zalecano ograniczenie spożycia białka w celu wyrównania hiperfosfatemii. Obecnie wiadomo, że takie postępowanie skutkuje niedożywieniem białkowym, co znacznie pogarsza stan kliniczny chorego. Współczesne zalecenia dietetyczne dążą do zachęcania chorych do spożywania produktów białkowych o małej zawartości fosforu oraz unikania żywności przetworzonej z dodatkiem środków konserwujących [9].

Analiza żywności pod względem zawartości fosforanów prezentowana przez D’Alessandro i wsp. [16] wykazała, że najwięcej fosforu w produktach spożywczych znajduje się w żółtku jaj, twardych serach, orzechach, niektórych rybach i mięsie. Analiza ilości fosforu (w miligramach) przypadającej na gram białka pokazała, że produkty białkowe znacząco różnią się między sobą zawartością fosforanów. Uznano, iż najbardziej korzystne dla zdrowia chorych na PCHN są produkty białkowe zawierające do $12 \mathrm{mg}$ fosforu/ $1 \mathrm{~g}$ białka.

Taylor i wsp. [19] zasugerowali, że białko jaja jest dobrym źródłem białka o wysokiej wartości biologicznej, a zarazem niskiej zawartości fosforu $(<2 \mathrm{mg} / \mathrm{g})$. W badaniu pilotażowym, przeprowadzonym wśród pacjentów hemodializowanych, zastąpiono mięso białkiem jaja kurzego, co skutkowało zmniejszeniem stężenia fosforanów w surowicy przy jednoczesnym zachowaniu prawidłowego stężenia albumin. W grupie chorych z hiperfosfatemią niewielu badanych było świadomych, że spożywanie białka jaja kurzego stanowi „bezpieczne” źródło białka, stąd zaledwie co trzecia osoba wskazała właściwą odpowiedź. Badani z grupy z normofosfatemią wykazali się lepszą znajomością tematu - zagadnienie to było znane ponad połowie respondentów.

Kontrolowanie ilości spożywanego fosforu w życiu codziennym jest bardzo trudne. Istotne znaczenie ma tu stałe poradnictwo dietetyczne w ośrodkach opiekujących się chorymi na przewlekłą chorobę nerek. Pacjenci potrzebują informacji odnośnie do zawartości fosforu w poszczególnych produktach. Edukacja terapeutyczna nie powinna ograniczać się jedynie do informowania chorych o produktach, których powinni unikać, ale przede wszystkim zapewnić chorym alternatywne rozwiązania. D'Alessandro i wsp. przedstawili specjalnie zaprojektowaną piramidę produktów żywieniowych zalecanych w diecie chorych $\mathrm{z}$ hiperfosfatemią. Może ona stanowić pomocne narzędzie w pracy pielęgniarki $[16,17,18]$. Przedstawiona piramida składa się z sześciu poziomów, na których zamieszczono produkty żywnościowe od najmniejszej do największej zawartości w nich fosforanów.

Na samym dole piramidy zamieszczono składniki wolne od fosforu, tj. oliwa z oliwek, białko jaja, warzywa, owoce. Produkty te nie podlegają ograniczeniu. Wyjątek stanowią chorzy na cukrzycę, z uwagi na zawartość glukozy. Pacjenci z hiperkalemią powinni stosować metody eliminacji potasu z pokarmów [16].

Drugi poziom obejmuje głównie pokarmy roślinne bogatsze $\mathrm{w}$ fosfor, ale ze względu na obecność fityny ich 
laemia should use methods of eliminating potassium from food [16].

The second level mainly includes plant foods that are richer in phosphorus, but due to the presence of phytin, their absorption is limited. These products include cereals (white bread, pasta, rice, corn flakes) or legumes (peas, broad beans, soya). The suggested intake of the above-mentioned foods is $2-3$ portions per day. This level also contains dairy products, i.e. yoghurt, kefir, buttermilk, milk, the recommended consumption of which is up to 1 serving per day. The knowledge of the respondents from both groups was poor. The respondents did not know what kind of baked goods are most recommended for hyperphosphataemia. Merely every fourth respondent in both represented groups indicated white wheat bread as the preferred one. One in four respondents with hyperphosphataemia and every second respondent in the group with normophosphataemia indicated that it was safe to consume up to one glass of milk or yoghurt per day.

The third level includes selected foods of animal origin with a relatively low phosphorus content. These include lamb, rabbit meat, pork ham, pork loin, chicken, beef or fish such as trout, tuna, cod, hake, and sole. It is recommended to select farmed fish carefully because of the unknown way they are fed by breeders. The suggested consumption of the above products is 1 portion per day. The fourth level contains high-protein products with a moderate phosphorus content, including turkey, squid, shrimp, salmon, giblets, curd cheese, and mozzarella. They should not be consumed more often than once a week [16].

When analysing the data obtained in the survey, it was noted that only one in four respondents in the group with hyperphosphataemia would choose meats with a moderate phosphorus content to compose their meal. In the group with normophosphataemia, almost half of respondents were able to indicate which meat products can be consumed safely.

The fifth level consists of products rich in phosphorus, such as nuts, hard cheese, blue cheese, egg yolk. Their intake should be limited to 2-3 times a month.

The top of the pyramid includes products containing preservatives, i.e. carbonated beverages, processed cheese, processed meat and fish. It is not recommended to consume these products.

In the group of patients with hyperphosphataemia, more than half of the respondents indicated hard cheeses as not recommended products, while in the group of patients with normophosphataemia, almost $90 \%$ of respondents knew which of the cheeses consumed may adversely affect calcium and phosphate metabolism. Considering the method of food preparation, the authors of the pyramid recommend cooking as the preferred method due to additional food demineralization $[9,16]$. Controlling phosphorus intake is a complex and difficult task. The presented food pyramid makes it easier for patient to select foods and compose a menu in order to maintain phosphate intake within the range of 700 $-1000 \mathrm{mg} /$ day, while preventing malnutrition. wchłanianie jest ograniczone, są to zboża (biały chleb, makaron, ryż, płatki kukurydziane) lub rośliny strączkowe (groch, bób, soja). Sugerowane spożycie tych pokarmów wynosi 2-3 porcje dziennie. Na tym poziomie zamieszczono także produkty mleczne, tj. jogurt, kefir, maślankę, mleko, których zalecane spożycie wynosi do 1 porcji dziennie. Wiedza respondentów z obu grup w tym zakresie była mała. Badani nie wiedzieli, jaki rodzaj pieczywa jest najkorzystniejszy w przypadku hiperfosfatemii. Zaledwie co czwarty badany w obu reprezentowanych grupach wskazał pieczywo białe pszenne jako preferowane. Spożywanie mleka, jogurtów w bezpiecznej ilości do szklanki dziennie zaznaczył co czwarty badany z hiperfosfatemią, ale już co drugi badany $\mathrm{w}$ grupie $\mathrm{z}$ normofosfatemią.

Trzeci poziom obejmuje wybrane pokarmy pochodzenia zwierzęcego ze względnie małą zawartością fosforu. Zalicza się do nich jagnięcinę, mięso królika, szynkę wieprzową, schab, kurczaka, wołowinę lub ryby, takie jak pstrąg, tuńczyk, dorsz, morszczuk, sola. Zaleca się ostrożne dobieranie ryb hodowlanych $\mathrm{z}$ uwagi na niewiadomy sposób karmienia ich przez hodowców. Sugerowane spożycie tych produktów to 1 porcja dziennie. Czwarty poziom zawiera produkty wysokobiałkowe z umiarkowaną zawartością fosforu, do których należą indyk, kalmary, krewetki, łosoś, podroby, ser twarogowy, mozzarella. Ich spożycie nie powinno być częstsze niż raz w tygodniu [16].

Analizując dane pozyskane w badaniu ankietowym, zwrócono uwagę, że zaledwie co czwarty badany $\mathrm{w}$ grupie $\mathrm{z}$ hiperfosfatemią do komponowania posiłku wybrałby mięsa $\mathrm{z}$ umiarkowaną zawartością fosforu. W grupie z normofosfatemią już prawie połowa respondentów potrafiła wskazać bezpieczne produkty mięsne. Piąty poziom zawiera produkty stanowiące bogate źródło fosforu, takie jak orzechy, sery żółte, sery pleśniowe, żółtko jaj z zaleceniem ograniczenia ich spożycia do 2-3 razy w miesiącu.

Szczyt piramidy obejmuje produkty zawierające konserwanty, tj. napoje gazowane, serki topione, przetworzone mięsa i ryby - ich konsumpcji nie zaleca się.

$\mathrm{W}$ grupie chorych z hiperfosfatemia ponad połowa badanych uznała twarde sery za produkty niewskazane, natomiast wśród osób z normofosfatemią prawie $90 \%$ respondentów wiedziało, które ze spożywanych serów mogą wpływać niekorzystnie na gospodarkę wapniowo-fosforanową.

Biorąc pod uwagę sposób przyrządzania potraw, twórcy piramidy zalecają gotowanie jako metodę preferowaną $\mathrm{z}$ uwagi na dodatkowe demineralizacje pokarmów $[9,16]$.

Kontrola spożycia fosforu jest złożonym i trudnym zadaniem. Prezentowana piramida żywienia ułatwia chorym dobieranie pokarmów i komponowanie jadłospisu tak, by utrzymać spożycie fosforanów w granicach 700-1000 mg/dobę, jednocześnie nie dopuszczając do niedożywienia. 


\section{CONCLUSIONS}

1. Patients' knowledge the possibilities of preventing hyperphosphataemia is insufficient and needs to be supplemented.

2. Significant differences between the knowledge of patients with hyperphosphataemia and the group with normophosphataemia were observed. Patients with normophosphataemia more often responded correctly in terms of meat selection, the way to consume eggs, dairy products, cheese as well as the consumption of carbonated beverages.

3. Neither gender nor the duration of renal replacement therapy had an impact on the knowledge of dietary recommendations concerning phosphorus consumption.

\section{WNIOSKI}

1. Stan wiedzy chorych na temat możliwości zapobiegania hiperfosfatemii jest niewystarczający i wymaga uzupełnienia.

2. Zaobserwowano istotne różnice pomiędzy stanem wiedzy chorych $\mathrm{z}$ hiperfosfatemia a grupą $\mathrm{z}$ normofosfatemią. Chorzy z normofosfatemią częściej odpowiadali prawidłowo $\mathrm{w}$ zakresie doboru mięs, sposobu spożywania jaj, nabiału, serów i napojów gazowanych.

3. Ani płeć, ani czas trwania leczenia nerkozastępczego nie miały wpływu na znajomość zaleceń dietetycznych dotyczących spożycia fosforu.

\section{Author's contribution}

Study design - A. Janus, M. Holecki

Data collection - A. Janus, G. Kawecki

Data interpretation - A. Janus, M. Holecki, A. Hawrot-Kawecka, G. Kawecki

Statistical analysis - A. Janus, M. Holecki

Manuscript preparation - A. Janus, M. Holeck

Literature research - A. Janus, M. Holecki, A. Hawrot-Kawecka, G. Kawecki

\section{REFERENCES}

1. Wyskida K., Klejn D., Sadowski L., Koźmiński P., Ciepał J., Hudziak G., Rotkegel S., Tochowicz S., Rowiński M., Arendt-Królikowska M., Uba A., Chudek J. Czynniki wpływające na złe wyrównanie zaburzeń gospodarki wapniowo-fosforanowej u chorych z przewlekła chorobą nerek leczonych powtarzanymi hemodializami. Nefrol. Dial. Pol. 2012(2); 16: 75-79.

2. Wajdlich M., Pietrasik P., Jarzebski T., Lewarska I., Olejniczak I., Banasiak M., Lipińska-Ojrzanowska A., Ojrzanowski M., Kurnatowska I., Nowicki M. Współpraca z lekarzem i przestrzeganie zaleceń medycznych przez pacjentów w różnych stadiach przewlekłej choroby nerek Nefrol. Dial. Pol. 2011; 15(1) $33-38$.

3. Gutiérrez O.M. Contextual poverty, nutrition and chronic kidney disease. Adv Chronic Kidney Dis. 2015; 22(1): 31-38, doi: 10.1053/j.ackd.2014.05.005. 4. Połubicka K., Kaczkan M., Małgorzewicz S., Król E., Białobrzeska B., Rutkowski B. Ocena wiedzy żywieniowej pacjentów z przewleką chorobą nerek w okresie leczenia zachowawczego Nefrol. Dial. Pol. 2013; 17(2): 56-60.

5. Afrasiabifar A., Karimi Z., Hassani P. Roy's Adaptation Model-Based Patien Education for Promoting the Adaptation of Hemodialysis Patients Iran Red. Crescent Med. J. 2013; 15(7): 566-572, doi: 10.5812/ircmj.12024

6. Nowicki M. Leczenie hiperfosfatemii w przewlekłej chorobie nerek. Nefrol. Dial. Pol. 2010: 14(3): 140-144.

7. Zhang C., Wen J., Li Z. Fan J. Efficacy and safety of lanthanum carbonate on chronic kidney disease-mineral and bone disorder in dialysis patients: a systematic review. BMC Nephrol. 2013; 14: 226, doi: 10.1186/1471-2369-14-226. 8. Chudek J., Czerwieńska B. Wiẹcek A. Zaburzenia mineralne i kostne pacjentów z przewlekłą chorobą nerek - patofizjologia i leczenie. Nefrol. Dial. Pol. 2008: 12(1): 47-52.

9. Beto J.A., Schury K.A., Bansal V.K. Strategies to promote adherence to nutritional advice in patients with chronic kidney disease: a narrative review and commentary. Int. J. Nephrol. Renovasc. Dis. 2016; 9: 21-33, doi: 10.2147 IJNRD.S76831.

10. Kalantar-Zadeh K. Patient education for phosphorus management in chronic kidney disease. Patient Prefer Adherence 2013; 7: 379-390, doi: 10.2147/ PPA.S43486

11. Askar A.M. Hyperphosphatemia. The hidden killer in chronic kidney disease. Saudi. Med. J. 2015; 36(1): 13-19, doi: 10.15537/smj.2015.1.9843. 12. Wyskida K., Klejn D., Sadowski L., Koźmiński P., Ciepał J., Hudziak G., Rotkegel S., Tochowicz S., Rowiński M., Arendt-Królikowska M., Uba A., Chudek J. Czynniki wpływajace na złe wyrównanie zaburzeń gospodarki fosforanowej u chorych z przewlekłą niewydolnością nerek leczonych powtarzanymi hemodializami. Nefrol. Dial. Pol. 2012; 16(2): 75-79.

13. Szurkowski M. Wpływ zindywidualizowanej edukacji na postepowanie zgodnie z zaleceniami lekarskimi i skuteczność leczenia zaburzeń gospodarki wapniowo-fosforanowej u pacjentów z przewlekłą chorobą nerek w stadium 5 poddawanych przewlekłej dializoterapii. Nefrol. Dial. Pol. 2015; 19(1): 32-39. 14. Pennick M., Poole L., Dennis K., Smyth M. Lanthanum Carbonate Reduces Urine Phosphorus Excretion: Evidence of High-Capacity Phosphate Binding. Ren Fail. 2012; 34(3): 263-270, doi: 10.3109/0886022X.2011.649657.

15. Covic A., Passlick-Deetjen J., Kroczak M., Büschges-Seraphin B., Ghenu A., Ponce P., Marzell B., de Francisco A.L. A comparison of calcium acetate/ magnesium carbonate and sevelamer-hydrochloride effects on fibroblast growth factor- 23 and bone markers: post hoc evaluation from a controlled, randomized study. Nephrol. Dial. Transplant. 2013; 28(9): 2383-2392, doi: 10.1093/ndt/ gft203.

16. D'Alessandro C., Piccoli G.B., Cupisti A. The "phosphorus pyramid": a visual tool for dietary phosphate management in dialysis and CKD patients. BMC Nephrol. 2015; 16: 9, doi:10.1186/1471-2369-16-9.

17. Karp H., Ekholm P., Kemi V., Itkonen S., Hirvonen T., Närkki S., LambergAllardt C. Differences among total and in vitro digestible phosphorus content of plant foods and beverages. J. Ren. Nutr. 2012; 22(4): 416-422, doi: 10.1053/j. jin.2011.04.004.

18. Benini O., D’Alessandro C., Gianfaldoni D., Cupisti A. Extra-phosphate load from food additives in commonly eaten foods: a renal and insidious danger for renal patients. J. Ren. Nutr. 2011; 21(4): 303-308.

19. Kalantar-Zadeh K., Gutekunst L., Mehrotra R., Kovesdy C.P., Bross R. Shinaberger C.S., Noori N., Hirschberg R., Benner D., Nissenson A.R., Kopple J.D. Understanding sources of dietary phosphorus in the treatment of patients with chronic kidney disease. Clin. J. Am. Soc. Nephrol. 2010; 5(3): 519-530, doi: 10.2215/CJN.06080809.

20. Taylor L.M., Kalantar-Zadeh K., Markewich T., Colman S., Benner D., Sim J.J., Kovesdy C.A. Dietary egg whites for phosphorus control in maintenance haemodialysis patients: A pilot study. J. Ren. Care. J. Ren. Care. 2011; 37(1): 16-24, doi: 10.1111/j.1755-6686.2011.00212.x.

21. Sehgal A.R., Sullivan C., Leon J.P., Bialostosky K. A public health approach to addressing hyperphosphatemia among dialysis patients J. Ren. Nutr. 2008; 18(3): 256-261, doi: 10.1053/j.jrn.2007.12.002.

22. Pollock J.B., Jaffery J.B. Knowledge of phosphorus compared with other nutrients in maintenance dialysis patients. J. Ren. Nutr. 2007; 17(5): 323-328, doi: $10.1053 /$ j.jrn.2007.05.009. 